\title{
STUDI OPTIMASI TAKAKURA DENGAN PENAMBAHAN SEKAM DAN BEKATUL
}

\author{
Arya Rezagama*, Ganjar Samudro \\ Program Studi Teknik Lingkungan, Fakultas Teknik, Universitas Diponegoro \\ JI. Prof Soedharto No 1, Tembalang, Semarang. \\ Email: arya_envi@yahoo.com
}

\begin{abstract}
ABSTRAK
Teknik pengomposan keranjang takakura telah banyak digunakan oleh rumah tangga di berbagai kota-kota besar di Indonesia. Pada sisi operasional terdapat kendala meliputi menurunnya efektifitas kinerja penguraian sampah organik sehingga sering terjadi kegagalan proses. Oleh karena itu, diperlukan suatu cara sederhana dalam meningkatkan kinerja porses pengomposan metode takakura. Secara garis besar, tahapan penelitian dibagi menjadi tahap persiapan, tahap pengomposan, dan tahap pengolahan data. Penambahan sekam dan bekatul divariasikan ke dalam lima kotak keranjang. Inokulum dalam komposter yang digunakan diambil dari keranjang milik mayarakat. Hasil penelitian menunjukkan penambahan sekam dan bekatul pada variasi 3. 4, dan 5 belum menunjukkan hasil signifikan dalam meningkatkan kinerja inokulum seperti kotak 1. Temperatur inokulum baru masih di atas temperatur variasi/kotak yang lain. Hal ini disebabkan pada inokulum baru dimungkinkan masih terdapat mikroorganisme aktif serta sisa makanan dan sirkulasi udara yang baik. Namun jika dibandingkan satu persatu, penambahan sekam dan bekatul mampu menaikkan temperatur pada awal penelitian dibanding kotak 2 pada rata-rata proses. Penambahan bekatul dan sekam menyebabkan peningkatan rasio $\mathrm{C} / \mathrm{N}$. Namun, peningkatan rasio $\mathrm{C} / \mathrm{N}$ tidak serta merta membuat kotak 2, 3, dan 4 memiliki proses degradasi yang lebih baik daripada inokulum baru yang ditandai dengan temperatur. Kandungan Karbon, Nitrogen, Phospor, dan Rasio $\mathrm{C} / \mathrm{N}$ keseluruhan kompos matang telah memenuhi standar dalam SNI 19-7030-2004, standar internasional, dan Departemen Pertanian, tetapi masih belum sesuai dengan standar Departemen Pertanian dan PT. PUSRI
\end{abstract}

Kata kunci: Komposter Takakura, Temperatur, Inokulum

\section{PENDAHULUAN}

Sampah organik domestik adalah sampah yang berasal dari pemukiman antara lain sisa makanan, daun, buah-buahan dan sisa sayuran. Sampah organik memiliki prosentase terbesar dalam keseluruhan produksi sampah dibanding sampah anorganik maupun sampah yang mengandung limbah berbahaya. Sampah organik dapat diolah dengan teknik pengomposan. Pengomposan merupakan dekomposisi terkontrol, proses alamiah penguraian bahanbahan organik sisa. Pengomposan mentransformasi material organik mentah menjadi bahan stabil secara biologi yang mengandung substansi humus (Cooperband, 2002).

Metode pengomposan Keranjang Takakura memiliki keunggulan dibandingkan dengan metode lain: 1. Praktis karena sangat cocok untuk perumahan dengan lahan yang tidak begitu lebar. Keranjang dapat ditempatkan di mana saja sesuai dengan kebutuhan dan ketersediaan lahan. 2. Mudah karena sampah hanya dimasukkan, setiap harinya. Tanpa ada perlakukan khusus seperti menambahkan cairan atau bahan-bahan tambahan yang lain. 3. Tidak berbau karena prosesnya melalui proses fermentasi, bukan pembusukan.

Pada sisi operasional terdapat kendala meliputi menurunnya efektifitas kinerja penguraian sampah organik sehingga sering terjadi kegagalan proses. Takakura yang telah digunakan secara benar pada periode yang lama akan menurun efektifitasnya yang ditunjukkan melalui penurunan temperatur proses. Semakin rendah temperatur akan mengakibatkan proses pengomposan menjadi semakin lama. Di sisi lain temperatur yang rendah $\left(<35^{\circ} \mathrm{C}\right)$ akan meningkatkan potensi tumbuhnya hewan, kutu, jamur yang tidak diinginkan. Maksud dari penelitian ini adalah untuk mengetahui pengaruh penambahanan sekam dan bekatul pada kompos Takakura dalam meningkatkan efektivitas Komposter Takakura rumah untuk menguraikan sampah organik. Sedangkan tujuan dari penelitian ini adalah (1) untuk menganalisis pengaruh penambahan serbuk gergaji dan sekam terhadap peningkatan temperatur proses pengomposan; (2) untuk menganalisis 
perubahan rasio $\mathrm{C} / \mathrm{N}$ dari proses pengomposan; (3) untuk menganalisis karakteristik kompos matang.

\section{METODOLOGI}

Lingkup wilayah penelitian berada di Laboratorium Teknik Lingkungan. Penelitian ini dilakukan selama enam bulan (Juni - November 2014). Tahap persiapan dilakukan selama dua bulan, tahap pengambilan data kompos dilaksanakan selama dua bulan, dan tahap penyusunan laporan dilakukan selama dua bulan.

Secara garis besar tahapan penelitian dibagi menjadi tahap persiapan, tahap pengomposan, dan tahap pengolahan data. Pengambilan sampel dilakukan sebagai bahan dalam penelitian ini berupa inokulum dalam Komposter Takakura yang telah lama digunakan masyarakat. Kriteria sampel inokulum yang dipergunakan ialah komposter telah digunakan minimal tiga bulan, bentuk fisik inokulum remah, warna cokelat kehitaman, kelembaban sekitar $50 \%$ namun temperaturnya rendah atau inokulum dapat bekerja tetapi membutuhkan waktu lama untuk mengurainya.

\section{HASIL DAN PEMBAHASAN}

\section{Fluktuasi temperatur}

Penambahan sekam dan bekatul pada variasi 3, 4, dan 5 belum menunjukkan hasil signifikan dalam meningkatkan kinerja inokulum seperti kotak 1. Temperatur inokulum kotak 1 masih di atas temperatur variasi yang lain. Hal ini disebabkan pada inokulum baru dimungkinkan masih terdapat mikroorganisme aktif serta sisa makanan dan sirkulasi udara yang baik. Namun, jika dibandingkan satu persatu, penambahan sekam dan bekatul mampu menaikkan temperatur pada awal penelitian dibanding kotak 2 pada rata-rata proses. Fluktuasi suhu dipengaruhi oleh proses penguraian glukosa

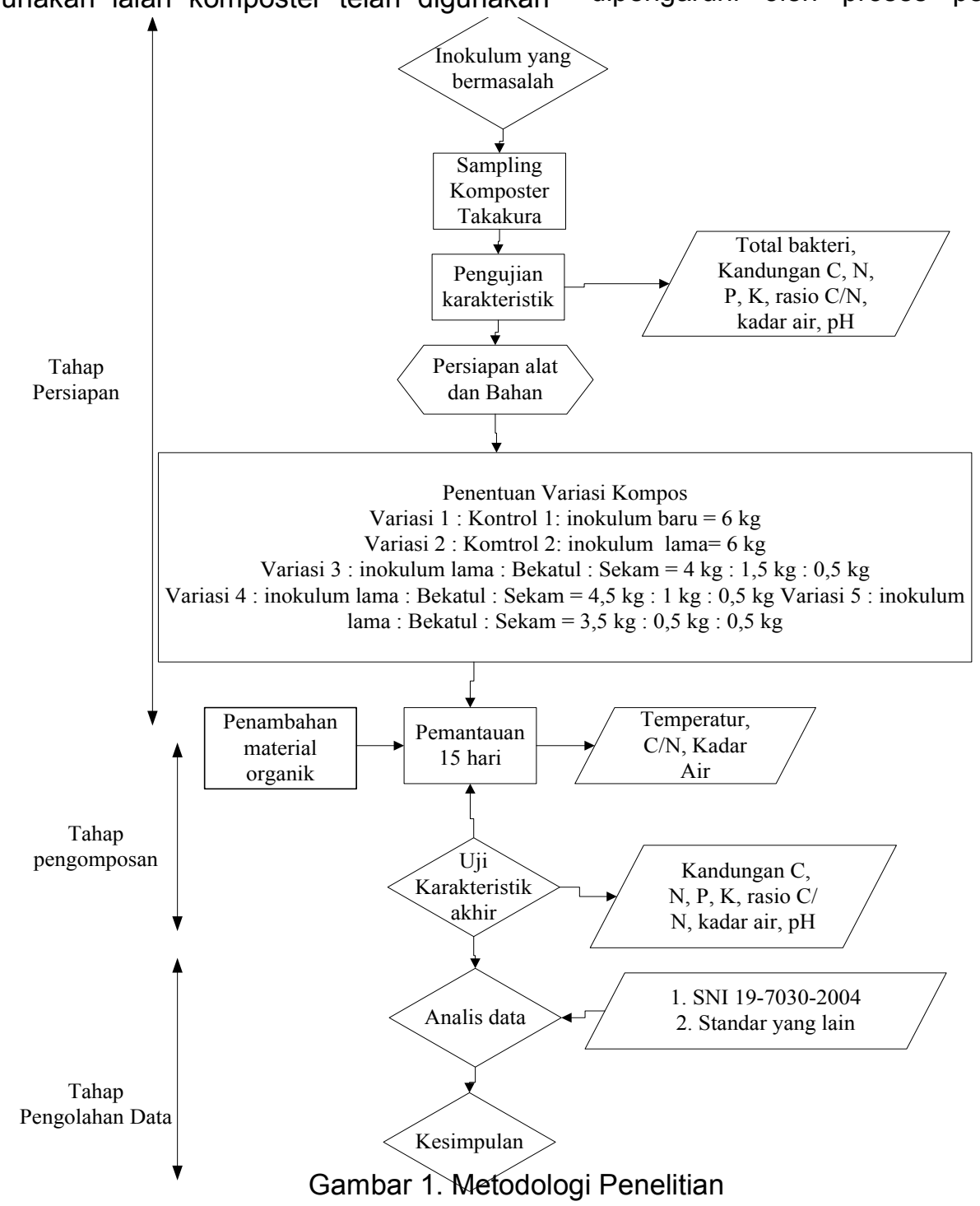


dalam nasi yang ditambahkan tiap dua hari sekali. temperatur akan meningkat dalam duapuluh empat jam dan turun kembali pada waktu selanjutnya. Pada suhu yang tinggi $\left(>40^{\circ} \mathrm{C}\right)$ terjadi proses penguapan air yang ada dalam inokulum, sehingga perlu penambahan air secara periodik menjadi lebih banyak. Pada hari ke enambelas fluktuasi temperatur mulai berkurang dan cenderung menjadi stabil.

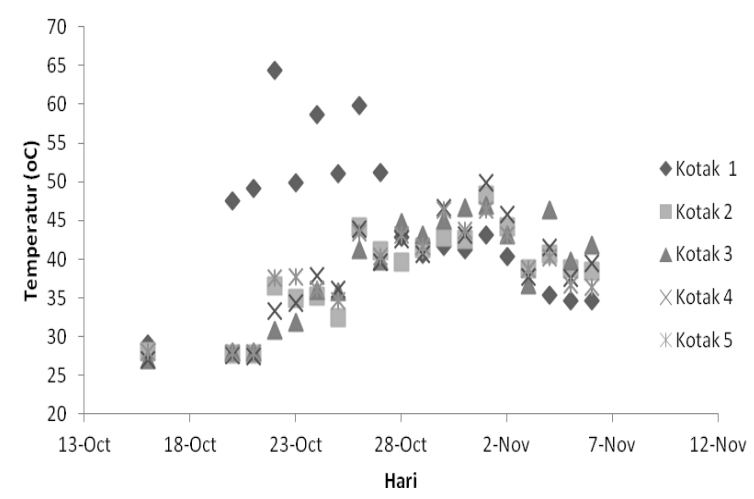

\section{Gambar 2. Grafik Temperatur Inokulum} Semua Variasi

Kotak 1 merupakan inokulum baru yang dibuat pada bulan Oktober di kantor Bintari. Inokulum ini mencapai temperatur tertinggi pada hari ke-empat sebesar $64^{\circ} \mathrm{C}$ dan terendah pada hari ke-18 sebesar $35^{\circ} \mathrm{C}$. Proses perombakan nasi berlangsung lebih cepat. Proses komposting sangat dipengaruhi oleh profil temperatur. Perubahan temperatur menandakan adanya pola aktivitas mikrobiologi yang sedang bekerja. Proses pengomposan berlangsung optimal dengan bantuan mikroorganisme thermofilik (45$60^{\circ} \mathrm{C}$ ). Jika suhu pengomposan terlalu tinggi hingga $>60^{\circ} \mathrm{C}$ maka sedikit jumlah mikroorganisme yang dapat bertahan (Fogarty \& Tuovinen, 1991, p. 228). Temperatur menurun drastis karena penambahan air terlalu banyak dimana penguapan semakin berkurang akibat puncak temperatur tidak tercapai. Pada inokulum baru terdapat kandungan bekatul yang memiliki rasio $\mathrm{C} / \mathrm{N}$ tertinggi sehingga banyak Karbon yang harus diuapkan dalam bentuk $\mathrm{CO}_{2}$ dengan temperatur terukur tinggi.

Mikroorganisme termofilik hidup pada temperatur $45-65^{\circ} \mathrm{C}$ dan bertugas mengkonsumsi karbohidrat dan protein sehingga bahan kompos dapat terdegradasi dengan cepat. Mikroorganisme ini berupa Actinomycetes dan jamur termofilik. Sebagian dari Actinomycetes mampu merombak selulosa dan hemiselulosa. Jamur termofilik hidup pada temperatur 40 $60^{\circ} \mathrm{C}$, tetapi mati pada temperatur di atas $60^{\circ} \mathrm{C}$. Kemudian proses dekomposisi mulai melambat dan temperatur puncak dicapai. Temperatur pengomposan lebih $50^{\circ} \mathrm{C}$ selama 24 jam efektif dalam membunuh mikroorganisme pathogen, khusunya Salmonella, Campylobacter dan $C$. perfringens. Setelah 32 jam pada suhu yang sama terjadi penurunan yang signifikan terhadap telur virus, fungi, dan parasit. Terbentuknya amonia juga berperan dalam pengurangan bakteri di sekitar permukaan kompos. (Macklin dkk, 2008).

Kotak 2 berupa kontrol inokulum lama tanpa penambahan bekatul dan sekam. Inokulum ini mencapai temperatur tertinggi pada hari ke-14 sebesar $48^{\circ} \mathrm{C}$ dan terendah pada hari pertama sebesar $28^{\circ} \mathrm{C}$. Temperatur rata-rata ialah $37^{\circ} \mathrm{C}$ yang berada pada fase mesofilik. Saat penguraian nasi, suhu mampu mencapai termofilik dan turun kembali selanjutnya. Kotak 3 berupa inokulum sampel dengan penambahan sekam dan bekatul dengan proporsi 0,5 dan 1,5 (proporsi penambahan bekatul lebih banyak). Inokulum ini mencapai temperatur tertinggi pada hari ke-11 sebesar $47^{\circ} \mathrm{C}$ dan terendah pada hari pertama sebesar $28^{\circ} \mathrm{C}$. Temperatur rata-rata ialah $37,6^{\circ} \mathrm{C}$ berada pada fase mesofilik.

Kotak 4 berupa inokulum sampel dengan penambahan sekam dan bekatul dengan proporsi 0,5 dan 1 . Inokulum ini mencapai temperatur tertinggi pada hari ke-11 sebesar $51^{\circ} \mathrm{C}$ dan terendah pada hari pertama sebesar $28^{\circ} \mathrm{C}$. Temperatur rata-rata ialah $37,5^{\circ} \mathrm{C}$ berada pada fase mesofilik. Kotak 5 berupa inokulum sampel dengan penambahan sekam dan bekatul secara seimbang dengan proporsi 0,5 dan 0,5 . Inokulum ini mencapai temperatur tertinggi pada hari ke sebelas sebesar $49^{\circ} \mathrm{C}$ dan terendah pada hari pertama sebesar $28^{\circ} \mathrm{C}$. Temperatur rata-rata ialah $37,5^{\circ} \mathrm{C}$ berada pada fase mesofilik. Pada suhu mesofilik muncul bakteri Eumycetes dan Actinomycetes yang berperan utama dalam dekomposisi polimer rantai panjang, selulosa dan lignin (Bertoldi dkk, 2008: 163).

Penambahan bekatul bertujuan untuk menambah jumlah mikroorganisme yang ada dalam inokulum. Proses perkembangan akan sangat dipengaruhi ketersediaan nutrisi. Pada keadaan minim nutrisi mikroorganisme membentuk keseimbangan dengan mengurangi aktivitasnya dan juga sebaliknya. Oleh karena itu, penambahan bekatul tidak mempengaruhi kinerja inokulum jika tidak ditambah nutrisi. Sekam merupakan penyusun polimer polisakarida yang dikenal sebagai makromolekul karbohidrat. Unit dasar sekam adalah monosakarida yang sangat mudah difermentasi oleh mikroorganisme (Campbell, 2002). Sekam dapat digunakan untuk mempercepat proses pengomposan karena memperbaiki sirkulasi udara dalam komposter. Sekam sederhana membuat mikroorganisme cepat berkembang biak, tetapi ketika kandungan 
sekam tersebut habis maka jumlah bakteri berkurang yang ditunjukkan dengan penurunan temperatur.

\section{Fluktuasi nilai $\mathbf{C} / \mathbf{N}$}

Mikroorganisme akan mengikat Nitrogen yang tergantung dari ketersediaan karbon pada proses pengomposan. Apabila ketersediaan karbon terbatas (nisbah $\mathrm{C} / \mathrm{N}<20$ ) maka tidak akan cukup energi untuk mengikat Nitrogen bebas (Sutanto, 2002). Nitrogen akan dibebaskan dalam bentuk $\mathrm{NH}_{3}{ }^{+}$dan hasil kompos berkualitas rendah. Gambar 3 menunjukkan bahwa dengan penambahan bekatul yang lebih banyak akan mengakibatkan rasio $\mathrm{C} / \mathrm{N}$ menjadi semakin tinggi yang ditunjukkan oleh kotak 3 .

Penambahan bekatul dan sekam menyebabkan peningkatan rasio $\mathrm{C} / \mathrm{N}$. Penambahan bekatul akan meningkatkan jumlah mikroorganisme akibat konsumsi karbon juga tersedia. Sementara itu, Nitrogen yang terbentuk sebagai Nitrat dan Amonia semakin banyak. Dari kotak 1,2, 3, 4, dan 5 tampak bahwa pereduksian tercepat dialami oleh variasi 4. Hal ini dikarenakan banyaknya nitrat yang menguap ke udara pada kondisi termofilik. Pada kotak dua memiliki nilai rasio $\mathrm{C} / \mathrm{N}$ yang paling rendah di awal akibat inokulum tersebut hampir matang. Peningkatan rasio $\mathrm{C} / \mathrm{N}$ tidak serta merta membuat kotak 2,3, dan 4 memiliki proses yang lebih baik daripada inokulum baru yang ditandai dengan temperatur.

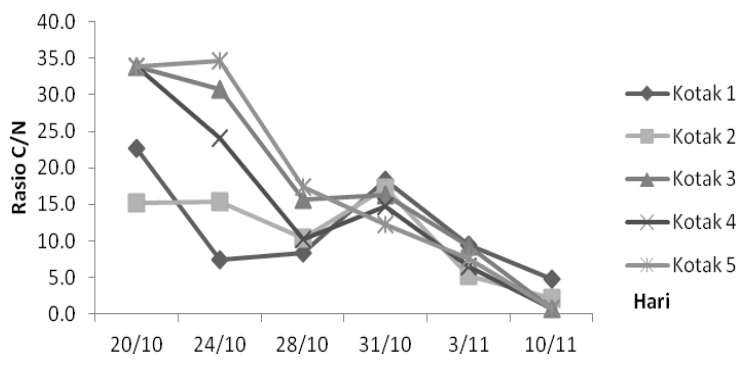

Gambar 3. Nilai perubahan rasio C/N terhadap waktu

Secara keseluruhan kompos mengalami penurunan rasio $\mathrm{C} / \mathrm{N}$ sampai pada akhirnya dengan rasio $\mathrm{C} / \mathrm{N}$ tanah. Sehingga dapat disimpulkan bahwa proses pengomposan ini telah berhasil. Simpel carbon mudah digunakan dalam proses metobolisme dan mineralisasi heterotropic dan heterogenous microflora. Karbon digunakan sebagai sumber energi mikroorganisme (Bertoldi dkk, 2008: 158). Nilai Carbon di awal berpengaruh terhadap proses pengomposan. Terjadi penurunan nilai Karbon dari awal pengomposan hingga akhir hingga mendekati rasio $\mathrm{C} / \mathrm{N}$ tanah.

\section{Analisis Karakteristik Kompos Matang}

Dari hasil penyaringan, dihasilkan kompos matang yang mempunyai bentuk fisik sama pada setiap variasi campuran kompos. Proses penjemuran mengurangi jumlah kadar air yang ada dalam kompos untuk mempermudah proses penyaringan. Rasio $\mathrm{C} / \mathrm{N}$ keseluruhan kompos matang telah memenuhi rasio $\mathrm{C} / \mathrm{N}$ yang disyaratkan dalam SNI 19-7030-2004, internasional standar dan Departemen Pertanian.

Tabel 1. Karakteristik Kompos Matang

\begin{tabular}{llllll} 
Kode & $\begin{array}{l}\text { C- } \\
\text { Organik }\end{array}$ & $\begin{array}{l}\mathrm{N} \\
\text { Total }\end{array}$ & $\begin{array}{l}\mathrm{P} \\
\text { Total }\end{array}$ & $\begin{array}{l}\text { Rasi } \\
\mathrm{O} / \mathrm{N}\end{array}$ & $\begin{array}{l}\text { Kaliu } \\
\mathrm{m}\end{array}$ \\
\hline $\begin{array}{l}\text { Inokulum } \\
\text { Baru } \\
\text { Inokulum }\end{array}$ & 10,38 & 2,16 & 0,07 & 4.8 & 0,01 \\
Lama & 7,29 & 3,54 & 0,14 & 2.1 & 0,19 \\
Kotak 5 & 9,42 & 12,19 & 0,11 & 0.8 & 0,09 \\
SNI 19- & $9,8-32$ & $>0,4$ & $>0,1$ & & $>0,2$ \\
7030-2004 & & & & & \\
$\begin{array}{l}\text { Departeme } \\
\text { n Pertanian }\end{array}$ & $>15$ & $>$ & & & \\
PT PUSRI & & 2,12 & & & $>2,00$
\end{tabular}

Sumber : SNI 19-7030-2004; Hadisuwito, 2007

Karakteristik kompos matang menunjukkan bahwa komposisi terbaik dari unsur hara yang dihasilkan ialah Kotak lima dengan kandungan Karbon terendah dan Nitrogen yang tertinggi sehingga rasio $\mathrm{C} / \mathrm{N}$ menjadi paling mendekati standar yang sesuai dengan rasio tanah. Unsur Kalium dan Phospor yang dikandung paling tinggi di antara variasi pada inokulum lama. Semakin banyak kandungan unsur Kalium dan Phospor semakin baik digunakan sebagai media tanam. Jika ditinjau secara fisik memang tidak ada perbedaan yang signifikan dari kesemua variasi tersebut.

Kandungan Karbon Organik pada semua kotak masih dibawah rentang mutu dalam SNI 19-7030-2004 yaitu sekitar 9,8 - 32. Jika dibandingkan dengan standar pupuk organik Departemen Pertanian, hasil pengomposan ini masih berada di bawah standar. Kandungan Nitrogen semua variasi kompos telah memenuhi standar SNI 19-7030-2004. Namun, pada standar DEPTAN masih di bawah persyaratan. Kotak lima memiliki kadar Nitrogen tertinggi. Unsur Nitrogen dibutuhkan tanaman untuk pembentukan klorofil dan protein. Kekurangan zat ini mengakibatkan ukuran mengecil dan menguning karena kekurangan karbohidrat yang dihasilkan dari klorofil (Hadisuwito, 2007: 31). Kadar Fosfor pada semua variasi 1, 2, dan 5 telah memenuhi standar SNI 19-7030-2004 yaitu lebih dari $0,1 \%$. Jika dibandingkan dengan standar PT PUSRI dan pupuk organik pasar maka kadar Fosfor pada metode ini masih 
dibawah standar yang kurang dari 1,3\% dan $1,6 \%$. Kadar tertinggi pada inokulum lama sebesar 0,14. Bila dibandingkan dengan kandungan unsur makro yang lain maka peningkatan kadar Fosfor akan berbanding lurus dengan kadar Nitrogen dan Kalium.

\section{KESIMPULAN}

Penambahan sekam dan bekatul pada variasi 3,4 , dan 5 belum menunjukkan hasil signifikan dalam meningkatkan kinerja inokulum seperti kotak 1. Temperatur inokulum kotak 1 masih di atas temperatur variasi yang lain. Hal ini dikarenakan pada inokulum baru dimungkinkan masih terdapat mikroorganisme aktif serta sisa makanan dan sirkulasi udara yang baik. Namun jika dibandingkan satu persatu, penambahan sekam dan bekatul mampu menaikkan temperatur pada awal penelitian dibanding kotak 2 pada rata-rata proses. Penambahan bekatul dan sekam menyebabkan peningkatan rasio $\mathrm{C} / \mathrm{N}$. Namun, peningkatan rasio $\mathrm{C} / \mathrm{N}$ tidak serta merta membuat kotak 2, 3, dan 4 memiliki proses yang lebih baik daripada inokulum baru yang ditandai dengan temperatur. Kandungan karbon, Nitrogen, Phospor, dan Rasio $\mathrm{C} / \mathrm{N}$ keseluruhan kompos matang telah memenuhi standarn dalam SNI 19-7030-2004, internasional standar dan Departemen Pertanian, tetapi masih belum sesuai dengan standar Departemen Pertanian dan PT. PUSRI.

\section{DAFTAR PUSTAKA}

Bertoldi, M. d., Vallini, G., \& Pera, A. (2008, April 2). sage publication. Retrieved mei 15 , 2009, from http://www.sagepub.com/cgi/content/refs/ $1 / 1 / 157$

Campbell, N. A. (2002). Biologi (Vol. V). Jakarta: Erlangga.

Cooperband, L. (2002, Maret 29). The Art and Science of Composting. (University of Wisconsin-Madison) Retrieved Maret 3, 2009, from cias: http://www.cias.wisc.edu/wpcontent/uploads/2008/07/artofcompost.p df

Fogarty, A. M., \& Tuovinen, O. H. (1991). Retrieved mei 2009, 6, from Microbiological Degradation of Pesticides in Yard: http://mmbr.asm.org/

Hadisuwito, S. (2007). Membuat Pupuk Kompos Cair. Jakarta: AgroMedia.
Macklin, K., Hess, J., \& Bilgili, S. (2008). InHouse Windrow Composting and Its Effects on Foodborne Pathogens. Retrieved Mei 12, 2009

SNI 19-7030-2004, S. :. (n.d.). Spesifikasi Kompos dari Sampah Domestik. Retrieved Maret 14, 2009, from Pekerjaan Umum: http//www.pu.go.idbalitbangSNIpdfSNI\% 2019-7030-2004.pdf

Sutanto, R. (2002). Penerapan pertanian organik: pemasyarakatan dan pengembangannya. Yogyakarta: Kanisius. 